
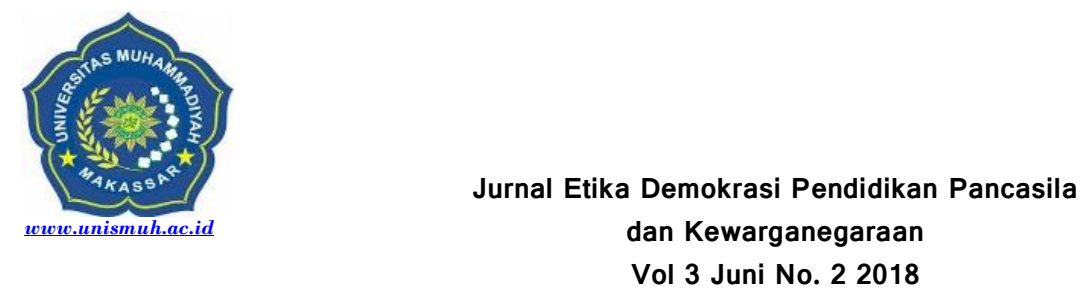

Jurnal Etika Demokrasi

\title{
Efektifitas Pembelajaran PPKn dengan Pendekatan Saintifik pada SMP Negeri 40
}

\author{
Makassar
}

\author{
Musdalifah Syahrir \\ Pendidikan Pancasila dan Kewarganegaraan FKIP Universitas Muhammadiyah Makassar \\ musdalifahsyahrir@unismuh.ac.id ${ }^{1)}$
}

\begin{abstract}
The study aims at obtaining the description of the effectiveness of PPKn learning using scientific approach at SMPN 40 Makassar viewed from its implementation including (1) observing, (2) questioning, (3) experimenting, (4) associating, and (5) communicating. This study is descriptive qualitative research that describes the result of the study by describing the actual data obtained from the effectiveness of PPKn learning using scientific approach at SMPN 40 Makassar. The data source is selected by employing purposive sampling technique. Data is collected through interview, observation, and documentation. Data is analyzed using descriptive qualitative analysis by conducting data reduction, data presentation, conclusion or verification. The results of the study of the effectiveness of PPKn learning using scientific approach at SMPN 40 Makassar indicate that (1) the scientific approach in PPKn learning at SMPN 40 Makassar at the stage of observing, questioning, experimenting, associating, and communicating had been conducted effectively, $(2)$ the scientific approach is yet to make the PPKn learning effective at SMPN 40 Makassar, proved by the implementation of learning activity using scientific approach that there are constraints face by the teacher and students, the students are not active yet in following the learning process, and it has yet to achieve PPKn learning objective using scientific approach.
\end{abstract}

Keywords : Effectiveness of learning, scientific approach.

\begin{abstract}
Abstrak. Tujuan penelitian ini untuk mendapatkan gambaran efektifitas pembelajaran PPKn dengan pendekatan saintifik pada SMP Negeri 40 Makassar yang dilihat dari penerapannya yang meliputi: (1) Mengamati (Observing); (2) Menanya (Questioning); (3) Mengumpulkan informasi/mencoba (Experimenting); (4) Menalar/mengasosiasi (Associating); (5) Mengomunikasikan (Communicating). Penelitian ini termasuk pendekatan deskriptif kualitatif yaitu menggambarkan hasil penelitian dengan mendeskripsikan data-data aktual yang diperoleh dalam efektifitas pembelajaran PPKn dengan pendekatan saintifik pada SMP Negeri 40 Makassar. Sumber data dipilih secara purposive sampling (sampel bertujuan). Data dikumpulkan dengan menggunakan wawancara, observasi dan dokumentasi. Teknik analisis data dilakukan dengan teknik analisis deskriptif kualitatif, yaitu reduksi data, penyajian data, penarikan kesimpulan, atau verifikasi. Hasil penelitian efektifitas pembelajaran PPKn dengan pendekatan saintifik pada SMP Negeri 40 Makassar menunjukkan bahwa: (1) Pendekatan saintifik dalam pembelajaran PPKn SMP Negeri 40 Makassar pada tahap mengamati, menanya, mengumpulkan informasi/ mencoba, menalar/ mengasosiasi, dan mengomunikasikan belum terlaksana secara efektif. (2) Pendekatan saintifik belum dapat mengefektifkan pembelajaran PPKn pada SMP Negeri 40 Makassar. Hal ini terbukti dalam pelaksanaan kegiatan belajar dengan pendekatan saintifik masih ada beberapa kendala yang dihadapi oleh guru dan siswa, siswa belum aktif dalam mengikuti proses pembelajaran, serta belum dapat mencapai tujuan pembelajaran PPKn dengan pendekatan saintifik.
\end{abstract}

Kata kunci: Efektifitas pembelajaran, pendekatan saintifik. 


\section{PENDAHULUAN}

Undang-Undang Nomor 20 Tahun 2003 tentang Sistem Pendidikan Nasional menyatakan bahwa:

"Pendidikan adalah usaha sadar dan terencana untuk mewujudkan suasana belajar dan proses pembelajaran agar peserta didik secara aktif mengembangkan potensi dirinya untuk memiliki kekuatan spiritual keagamaan, pengendalian diri, kepribadian, kecerdasan, akhlak mulia, serta keterampilan yang diperlukan dirinya, masyarakat, bangsa, dan Negara".

Proses belajar mengajar merupakan serangkaian aktivitas yang terdiri dari persiapan, pelaksanaan, dan evaluasi pembelajaran. Ketiga hal tersebut merupakan rangkaian utuh yang tidak dapat dipisah-pisahkan. Persiapan belajar mengajar merupakan penyiapan satuap acara pelajaran (SAP) yang meliputi antara lain standar kompetensi dan kompetensi dasar, alat evaluasi, bahan ajar, metode pembelajaran, media/alat peraga pendidikan, fasilitas, waktu, tempat, dana, harapan-harapan, dan perangkat informasi yang diperlukan untuk mendukung pelaksanaan proses belajar mengajar. Kesiapan siswa, baik fisik maupun mental, juga merupakan hal penting. Jadi esensi persiapan proses belajar mengajar adalah kesiapan segala hal yang diperlukan untuk berlangsungnya proses belajar mengajar.

Pelaksanaan proses belajar mengajar, merupakan kejadian atau peristiwa interaksi antara pendidik dan peserta didik yang diharapkan menghasilkan perubahan pada peserta didik, dari belum mampu menjadi mampu, dari belum terdidik menjadi terdidik, dari belum kompeten menjadi kompeten. Inti dari proses belajar mengajar adalah efektifitasnya. Tingkat efektifitas pembelajaran sangat dipengaruhi oleh perilaku pendidik dan perilaku peserta didik. Perilaku pendidik yang efektif, antara lain mengajarnya jelas, menggunakan variasi metode pembelajaran, menggunakan variasi media/alat peraga pendidikan, antusiasme, memberdayakan peserta didik menggunakan pendekatan saintifik, menggunakan jenis pertanyaan yang membangkitkan, dan lain sebagainya. Sedang perilaku peserta didik, antara lain motivasi atau semangat belajar, keseriusan, perhatian, karajinan, kedisiplinan, keingintahuan, pencatatan, pertanyaan, senang melakukan latihan soal, dan sikap belajar yang positif. Pembelajaran semacam ini akan berjalan efektif melalui pendekatan saintifik.

Tujuan utama PPKn adalah untuk menumbuhkan wawasan dan kesadaran bernegara, sikap serta perilaku yang cinta tanah air dan bersendikan kebudayaan bangsa, Wawasan Nusantara, serta Ketahanan Nasional dalam diri para peserta didik warga negara Negara Kesatuan Republik Indonesia yang sedang mengkaji dan akan menguasai iptek dan seni. Kualitas warga negara akan ditentukan terutama oleh keyakinan dan sikap hidup bermasyarakat, berbangsa dan bernegara di samping derajat penguasaan ilmu pengetahuan dan teknologi yang dipelajarinya.

Sekolah adalah tempat untuk mencari ilmu. Guru dan siswa adalah komponen yang ada di dalamnya. Dalam proses belajar pasti ada suatu masalah. Contohnya di SMP Negeri 40 Makassar. Di sekolah ini banyak siswa yang mengalami kesulitan dalam belajar PPKn. Guru juga mengakui bahwa nilai PPKn siswa masih banyak yang kurang baik. Hal seperti ini, dapat terjadi karena dari siswanya yang kurang memperhatikan, siswa tidak senang pada saat belajar PPKn, kondisi psikologis anak, guru yang belum dapat memanfaatkan metode, media dan pendekatan pembelajaran, guru memberikan pelajaran hanya dengan satu arah, komunikasi antara guru dan siswa belum terjalin. Banyak hal yang dapat mengakibatkan masalah seperti yang terdapat di SMP Negeri 40 Makassar.

Untuk itu, peneliti ingin mencoba mengefektifitaskan pembelajaran dengan pendekatan saintifik pada pelajaran PPKn di SMP Negeri 40 Makassar. Karena dalam pendekatan saintifik ini, guru diwajibkan untuk merancang pembelajaran yang efektif dan sistematis. Dilengkapi dengan pendekatan saintifik yang menjadikan siswa berperan aktif dalam proses pembelajarannya. 
Dengan demikian, dalam permasalahan yang sering diungkapkan oleh siswa dan guru pada mata pelajaran PPKn. Kebanyakan siswa menganggap mata pelajaran ini sulit untuk dipahami. Untuk itu peneliti ingin meneliti efektifitas pembelajaran PPKn dengan pendekatan saintifik. Dalam penelitian ini, peneliti membatasi masalah yang akan diteliti.

Berangkat dari uraian di atas maka peneliti melakukan penelitian sehingga diperoleh bukti empirik. Namun dalam hal ini, khususnya yang berkaitan dengan efektifitas pembelajaran PPKn dengan pendekatan saintifik masih perlu dilakukan penelusuran, oleh karena belum ada hasil penelitian tentang efektifitas pembelajaran PPKn dengan pendekatan saintifik pada SMP Negeri 40 Makassar. Dengan adanya hasil penelitian ini akan memberikan gambaran bagi ilmuan untuk penelitian lebih lanjut.

Dari uraian latar belakang tersebut diatas, maka penulis dalam penelitian ini mengambil judul Efektifitas Pembelajaran PPKn Dengan Pendekatan Saintifik Pada SMP Negeri 40 Makassar.

\section{METODE PENELITIAN}

Penelitian ini termasuk pendekatan deskriptif kualitatif yaitu menggambarkan hasil penelitian dengan mendeskripsikan data-data aktual yang diperoleh dalam proses penelitian. Penelitian kualitatif ini juga bersifat alamiah dalam konteks bahwa segala sesuatu didalamnya merupakan suatu proses alamiah yang terjadi pada fenomena tersebut tanpa adanya proses manipulasi keadaan penelitian. Dalam hal ini untuk menggambarkan atau mendeskripsikan efektifitas pembelajaran PPKn dengan pendekatan saintifik.

Penelitian ini dimaksudkan untuk mencari tahu bagaimana efektifitas pembelajaran PPKn dengan pendekatan saintifik di SMP Negeri 40 Makassar maka lokasi penelitian utama diadakan di SMP Negeri 40 Makassar.

Fokus penelitian ini adalah efektifitas pembelajaran PPKn pada guru dan siswa dan langkah-langkah pendekatan saintifik yang dilakukan oleh guru dan siswa meliputi mengamati, menanya, mencoba, mengasosiasi, dan mengkomunikasikan.

Dalam penelitian ini, instrumen adalah peneliti sendiri. Setelah fokus penelitian menjadi jelas, maka instrumen penelitian dikembangkan secara sederhana yang dapat dipertajam serta dapat melengkapi data hasil wawancara, observasi, dan dokumentasi. Bentuk instrumen tersebut dikembangkan melalui fokus penelitian agar semua informasi yang diperoleh menjadi data yang akurat yang dibutuhkan dalam penelitian ini.

Jenis data yang dibutuhkan dalam penelitian ini terdiri atas data primer dan sekunder yang sifatnya kualitatif yang diperoleh dari hasil wawancara sebelum dan sesudah berada di lokasi penelitian. Data primer adalah data empiris yang diperoleh langsung dari lokasi penelitian. Data sekunder adalah data pendukung yang diperoleh dari berbagai sumbermelalui pengkajian dokumen atau literatur.

Penelitian ini dilakukan dengan mengikuti prosedur penelitian yaitu pada awal penelitian kelompok diberi pretest dan pada akhir penelitian diberi posttest. Kelompok ini diberi perlakuan Pembelajaran PPKn dengan pendekatan saintifik yang diberikan dalam satu kali pertemuan yaitu memberikan tugas kepada siswa. Prosedur yang ditempuh dalam penelitian ini dibagi menjadi dua tahap yaitu tahap persiapan dan tahap pelaksanaan. Adapun langkah-langkahnya yaitu:

1. Tahap persiapan

Sebelum melaksanakan Pembelajaran PPKn, terlebih dahulu melakukan beberapa persiapan sebagai berikut:

a. Mempersiapkan perangkat pembelajaran. Rencana pembelajaran yang dimaksud adalah rencana program pengajaran dan lembar kerja siswa yang dikembangkan oleh peneliti.

b. Menyiapkan instrumen pengumpulan data.

2. Tahap pelaksanaan

Tahap pelaksanaan penelitian, proses yang dilakukan sebagai berikut: 
a. Melaksanakan Pembelajaran PPKn dengan langkah-langkah sebagai berikut:

1) Menentukan lokasi di dalam kelas untuk melakukan proses pembelajaran yaitu di kelas VII dan IX.

2) Membagi kelompok. Siswa dibagi ke dalam 5 kelompok yang masingmasing kelompok terdiri dari 5-6 orang siswa.

3) Membuat panduan belajar pada waktu belajar di dalam kelas.

4) Guru mengajak siswa di dalam kelas berkumpul sesuai kelompoknya.

5) Guru memberikan panduan belajar kepada masing-masing kelompok dan memberikan penjelasan cara kerja kelompok.

6) Setiap kelompok dalam kelas yang sudah ditentukan dan melakukan proses pembelajaran.

7) Guru membimbing siswa dalam kerja kelompok.

8) Selesai waktu yang sudah ditentukan guru mengajak siswa untuk diskusi hasil kerja kelompok.

9) Guru membantu diskusi dan siswa diberi kesempatan memberi tanggapan.

10) Guru memberikan kesempatan kepada siswa untuk mengungkapkan hambatan/hal yang menyenangkan selama proses pembelajaran.

11) Melakukan evaluasi.

Teknik pengumpulan data yang digunakan dalam penelitian ini adalah :

a. Wawancara (interview), wawancara adalah suatu proses interaksi dan komunikasi verbal dengan tujuan untuk mendapatkan informasi penting yang diinginkan. Wawancara ditujukan kepada guru mata pelajaran PPKn dan siswa tentang efektifitas pembelajaran PPKn dengan pendekatan saintifik.

b. Observasi (pengamatan), observasi yang dilakukan dengan jalan pengamatan mengenai efektifitas pembelajaran PPKn dengan pendekatan saintifik. Pencatatan secara sistematik terhadap gejala-gejala yang tampak pada objek penelitian sehingga data yang diperoleh dapat dipertanggungjawabkan.

c. Dokumentasi, penulis telah melakukan pengkajian dokumen atau literatur yang berkaitan dengan efektifitas pembelajaran PPKn di SMP Negeri 40 Makassar. Hal ini dilakukan sebagai bahan pertimbangan untuk membandingkan pernyataan para informan atau responden dengan pernyataanpernyataan yang ada. Seperti rencana pelaksanaan pembelajaran, daftar hadir siswa, program tahunan dan semester, jadwal mengajar, serta fasilitas-fasilitas yang dimiliki oleh SMP Negeri 40 Makassar.

Kegiatan dalam analisis data dilakukan secara interaktif dan berlangsung secara berkesinambungan pada setiap tahapan penelitian sampai tuntas dengan langkah-langkah sebagai berikut :

1. Reduksi Data

Pada saat pengambilan data di lapangan penulis menggunakan teknik wawancara dengan sumber data, peneliti mencatat, menghimpun semua jawaban-jawaban yang dikemukakan oleh sumber data. Beragam data yang diperoleh ada yang jawabannya sama ada juga yang memberikan pandangan yang berbeda terhadap setiap pertanyaan yang diajukan, serta hasil studi dokumentasi.

2. Display Data

Setelah data yang diperoleh peneliti di lapangan dipilah dan dipilih hal-hal pokok yang difokuskan pada permasalahan yang ingin dikaji yakni efektifitas pembelajaran PPKn dengan pendekatan saintifik pada SMP Negeri 40 Makassar, langkah selanjutnya peneliti menyajikan data tentang efektifitas pembelajaran PPKn pada siswa dan guru. Penyajian data atau display data ini disajikan dalam bentuk narasi berdasarkan hasil 
wawancara yang telah dilakukan dengan informaninforman yang ada.

\section{Verifikasi Data}

Setelah itu dilakukan pemeriksaan keabsahan data hasil wawancara dengan sejumlah narasumber yang dijadikan informan penelitian serta membandingkan data tersebut dengan berbagai informasi yang terkait. Pada tahap ini, pengolahan data dianggap optimal apabila data yang diperoleh sudah layak dianggap lengkap dan dapat merepresentasikan masalah yang dijadikan obyek penelitian.

Keabsahan data dimaksudkan untuk memperoleh tingkat kepercayaan yang berkaitan dengan seberapa jauh kebenaran hasil penelitian. Untuk menetapkan keabsahan data, peneliti melakukan teknik pemeriksaan dan keabsahan data dengan melakukan uji krebilitas.

1. Uji krebilitas

a. Perpanjangan pengamatan

Perpanjangan pengamatan dilakukan apabila data yang ditemukan sebelumnya belum lengkap. Selain itu, perpanjangan pengamatan juga dapat dilakukan untuk mengecek kembali kebenaran data-data yang didapatkan sebelumnya.

b. Meningkatkan ketekunan

Teknik ketekunan pengamatan dilakukan dengan maksud mengadakan pengamatan dengan teliti, rinci, dan medalam serta berkesinambungan terhadap fenomena dan peristiwa yang terjadi pada latar penelitian, sehingga ditemukan hal-hal yang relevan dengan kepentingan penelitian. Dengan perkataan lain, ketekunan pengamatan bermaksud menemukan ciri-ciri dan unsur-unsur dalam situasi yang sangat relevan dengan masalah yang sedang dicari dan kemudian memusatkan diri pada hal-hal tersebut secara rinci.

\section{c. Triangulasi}

Teknik tringulasi dilakukan dengan maksud mengecek ulang derajat keterpercayaan data atau informasi yang telah diperoleh. Tringulasi yang dilakukan adalah tringulasi teknik dan tringulasi sumber. Tringulasi teknik dilakukan dengan menanyakan hal yang sama kepada informan melalui teknik yang berbeda yaitu melalui wawancara, observasi dan dokumentasi.
Sedangkan tringulasi sumber dilakukan dengan cara menanyakan hal yang sama melalui sumber yang berbeda.

\section{d. Member check}

Member check merupakan proses pengecekan data yang diperoleh peneliti kepada pemberi data. Tujuannya dilaksanakan member check ini adalah untuk menegathui sejauhmana kebenaran data yang telah diberikan oleh informan. Hasil member check tersebut apabila ada data yang tidak sesuai maka informan akan diberikan kesempatan untuk memberikan koreksi. Data yang telah dikoreksi itulah yang peneliti jadikan sebagai data dalam penelitian ini.

\section{PEMBAHASAN}

\section{Gambaran Umum Lokasi Penelitian}

Lokasi penelitian adalah Sekolah Menengah Pertama Negeri 40 Makassar yang terletak di jalan Aroeppala/Minasa Upa Timur no. 4 kelurahan Gunung Sari kecamatan Rappocini Makassar provinsi Sulawesi Selatan. Berdasarkan data sekolah, luas sekolah $5000 \mathrm{~m}^{2}$ dengan luas bangunan $252 \mathrm{~m}^{2}$. Sekolah ini didirikan dan beroperasi pada tahun 2009. Meskipun sekolah ini tergolong baru namun sekolah mengalami kemajuan yang pesat dibawah pimpinan kepala sekolah, guru-guru yang profesional dan para staf yang berkompeten. Kepala sekolah pertama dan yang memimpin sampai saat ini adalah $\mathrm{H}$. Rahmat Hidayat, S. Sos, S.Pd, MH. Adapun jumlah guru di sekolah ini yaitu sebanyak 37 orang dan staf Tata Usaha sebanyak 3 orang. Jumlah shift tiap hari ada dua yaitu pagi 07.30-12.30 dan siang 12.40-17.05.

Secara keseluruhan jumlah siswa pada tahun ajaran 2015/2016 sebanyak 449 orang, yang terdiri atas:

a. Kelas VII, dengan keseluruhan jumlah siswa sebanyak 144 orang dari 4 rombel.

b. Kelas VIII, dengan keseluruhan jumlah siswa sebanyak 157 orang dari 5 rombel.

c. Kelas IX, dengan keseluruhan jumlah siswa sebanyak 148 orang dari 5 rombel.

Kelengkapan fasilitas belajar di SMP Negeri 40 Makassar secara berkesinambungan terus ditingkatkan, dibenahi, dan dilengkapi untuk 
memenuhi persyaratan kebutuhan dalam menunjang terselenggaranya pendidikan yang maksimal, telah menyiapkan kelengkapan sarana dan prasarana, sebagai berikut:

a. Sarana belajar

1) Sumber belajar: buku, majalah, koran, video dan sebagainya.

2) Media pembelajaran: LCD, Computer, TV, Radio, DVD Player.

3) Alat praktik: peta dinding, globe, alat musik dan sebagainya.

b. Prasarana belajar

1) Ruang kelas

2) Ruang laboratorium IPA.

3) Ruang perpustakaan

4) Ruang kepala sekolah, guru, tata usaha dan OSIS

5) Mushallah, UKS, Koperasi sekolah, kantin sekolah, dan toilet

6) Lapangan olahraga

Pelaksanaan Kurikulum 2013 di SMP Negeri

40 Makassar. Kurikulum 2013 (K-13) adalah kurikulum yang berlaku dalam Sistem Pendidikan Indonesia. Kurikulum ini merupakan kurikulum tetap diterapkan oleh pemerintah untuk menggantikan Kurikulum-2006 (yang sering disebut sebagai Kurikulum Tingkat Satuan Pendidikan) yang telah berlaku selama kurang lebih 6 tahun. Kurikulum 2013 masuk dalam masa percobaanya pada tahun 2013 dengan menjadikan beberapa sekolah menjadi sekolah rintisan.

Pada tahun ajaran 2013/2014, tepatnya sekitar pertengahan tahun 2013, Kurikulum 2013 diimpelementasikan secara terbatas pada sekolah perintis, yakni pada kelas VII untuk SMP, sedangkan pada tahun 2014, Kurikulum 2013 sudah diterapkan untuk SMP Kelas VII dan VIII di SMP Negeri 40 Makassar.

Kurikulum 2013 memiliki empat aspek penilaian, yaitu aspek pengetahuan, aspek keterampilan, aspek sikap, dan perilaku. Di dalam Kurikulum 2013, terutama di dalam materi pembelajaran terdapat materi yang dirampingkan dan materi yang ditambahkan. Materi yang dirampingkan terlihat ada di materi Bahasa Indonesia, IPS, PPKn, dan sebagainya. Sedangkan materi yang ditambahkan adalah materi Matematika.

Pada tahun pelajaran 2015/2016, kurikulum 2013 diimplementasikan secara menyeluruh, yakni pada kelas VII, VIII, IX di SMP Negeri 40 Makassar.

Langkah-langkah Pendekatan Saintifik Pada Pembelajaran PPKn di SMP Negeri 40 Makassar

Dalam pelaksanaan proses pembelajaran PPKn dengan pendekatan saintifik harus mengikuti beberapa indikator seperti menanya, mencoba, mengamati, mengasosiasi, dan mengkomunikasikan. Hal ini perlu dilaksanakan agar kedepannya proses pembelajaran PPKn lebih baik dan mengalami kemajuan.

Berdasarkan data yang diperoleh peneliti di kelas menunjukkan bahwa pendekatan saintifik yang dijadikan acuan dalam melaksanakan seluruh pembelajaran di kelas. Pendekatan saintifik diklasifikasikan menjadi lima bagian yaitu mengamati, menanya, mencoba, mengasosiasi, mengkomunikasikan. Untuk tahap mengamati, peserta didik membaca teks atau mengamati film/gambar/photo/ilustrasi lain yang terdapat di dalam buku teks PPKn. Untuk tahap menanya, membuat dan mengajukan pertanyaan, tanya jawab, berdiskusi tentang informasi yang belum dipahami, informasi tambahan yang ingin diketahui, atau sebagai klarifikasi. Untuk tahap mencoba, mengamati objek/kejadian. Untuk tahap mengasosiasi, peserta didik dapat membandingkan informasi dari situasi yang terjadi saat ini dengan sumber bacaan yang terakhir diperoleh dengan sumber yang diperoleh dari buku untuk menemukan hal yang lebih mendalam. Sedangkan tahap mengkomunikasikan, peserta didik melaporkan kesimpulan atau generalisasi dalam bentuk lisan, tertulis atau produk lainnya.

Observasi ini merupakan yang pertama kali dilakukan peneliti di dalam kelas. Kelas yang di amati adalah kelas VII dan IX. Adapun yang diamati yaitu mengenai proses pembelajaran di dalam kelas.

Setelah guru masuk kelas guru mengucapkan salam kepada peserta didik. Kemudian guru menyiapkan peserta didik baik psikis maupun fisiknya dengan cara 
mempersilahkan peserta didik memeriksa pakaian, tempat duduk, dengan lingkungan sekitarnya apakah sudah bersih dan rapi atau belum. Setelah peserta didik dirasa siap untuk belajar, terlebih dahulu guru mengabsen peserta didik satu per satu guna mengetahui posisi tempat duduk siswa. Setelah itu guru bersama peserta didik melakukan proses pembelajaran. Dalam kegiatan selanjutnya guru melaksanakan semua aspek yang akan diamati, mulai dari apersepsi dan motivasi, penyampaian kompetensi dan rencana kegiatan, penguasaan materi pelajaran, penerapan strategi pembelajaran yang mendidik, penerapan pendekatan saintifik, pemanfaatan sumber belajar/media pembelajaran, pelibatan peserta didik dalam pembelajaran, penggunaan bahasa yang benar dan tepat dalam pembelajaran, dan penutup pembelajaran. Setelah itu guru mengakhiri pembelajaran dengan salam.

Jam 10.30-12.30 WITA, jam kelima, guru telah masuk kelas namun masih ada beberapa siswa yang belum masuk kelas karena istirahat. Sekitar jam 10.35 guru siap untuk memulai pembelajaran. Guru membuka dengan salam dan berdoa serta sedikit motivasi untuk memulai pembelajaran.

Setelah suasana kelas kondusif, guru melaksanakan pembelajaran PPKn dengan pendekatan saintifik yang diobservasi oleh peneliti atas pertimbangan guru PPKn. Pembelajaran PPKn dengan pendekatan saintifik dilaksanakan selama 80 menit, lalu dilanjutkan dengan peserta didik melaporkan kesimpulan atau generalisasi dalam bentuk lisan, tertulis atau produk lainnya.

Pada akhir pembelajaran guru melaksanakan tindak lanjut dengan memberikan arahan kegiatan berikutnya dan tugas pengayaan dan guru menutup pembelajaran dengan doa akhir kegiatan lalu salam.

Pada awal pembelajaran guru mengucapkan salam dan siswa secara serempak menjawab salam guru. Guru menyuruh siswa berdoa dan semua siswa terlihat membaca doa dengan keras dan kompak. Pada pendahuluan guru menyampaikan tujuan pembelajaran secara singkat dan sebagian siswa tampak memperhatikan penjelasan guru. Sebelum kegiatan inti, guru menyampaikan rencana kegiatan misalnya individual, kerja kelompok, dan melakukan observasi.

Pada kegiatan inti, tahap mengamati sudah diterapkan oleh guru secara baik, guru sudah memberikan materi dan menyuguhkan gambar secara jelas walaupun dengan singkat. Siswa terlihat memperhatikan walaupun terkadang masih sibuk dengan kegiatannya sendiri. Pada tahap menanya tidak ada siswa yang bertanya tetapi guru memberikan motivasi serta pertanyaan untuk menumbuhkan pemahaman siswa, siswa terlihat antusias menjawab pertanyaan yang diberikan oleh guru walaupun ada beberapa jawaban siswa yang tidak sesuai dengan pertanyaan yang diberikan oleh guru. Pada tahap mencoba guru membagi siswa menjadi kelompok kecil dan setiap kelompok terdiri dari empat atau lima siswa. Guru sudah memberikan instruksi tugas mengamati gambar/film/photo/ilustrasi lain dengan baik, siswa mengerjakan tugas yang diberikan oleh guru tetapi dengan kondisi yang kurang terkontrol, sehingga keadaan kelas terlihat ramai. Pada tahap menalar, guru menjelaskan tugas apa yang harus apa yang harus dilakukan terhadap gambar yang diberikan dan mengelilingi kelas untuk membimbing siswa dalam mengerjakan tugas yang diberikan. Siswa yang dilewati guru terlihat tenang, tetapi siswa yang tidak terkontrol masih sibuk mengerjakan tugas sambil bermain.

Tahap terakhir dalam mengomunikasikan, guru menyuruh beberapa siswa untuk maju mempresentasikan tugas yang telah diberikan, dan beberapa siswa maju mempresentasikan jawaban mereka dengan sikap malu-malu. Guru sudah memberikan tanggapan dari jawaban siswa, tetapi siswa yang lain kurang berpartisipasi dalam memberikan tanggapan terhadap jawaban temannya yang sedang maju di depan kelas. Pada akhir pembelajaran guru memberikan kesimpulan dan menutup kegiatan pembelajaran dengan salam.

Dengan demikian dapat disimpulkan bahwa pelaksanaan pembelajaran dimulai dari salam, pengkondisian peserta didik, mengabsen peserta 
didik, penyampaian materi, pertanyaan-petanyaan, diskusi untuk memecahkan permasalahan, kemudian dilanjutkan dengan presentasi kelompok dan tanya jawab, konfirmasi dari guru, kesimpulan dari peserta didik, penilaian, berdoa, dan salam. Penerapan pendekatan saintifik belum berjalan dengan lancar dan efektif karena masih ada beberapa kendala yang dihadapi oleh guru dan siswa dalam proses pembelajaran PPKn.

Efektifitas Pembelajaran PPKn dengan Pendekatan Saintifik Pada SMP Negeri 40 Makassar

Suatu pembelajaran dapat dikatakan efektif, apabila terjadi interaksi yang baik antara guru dengan siswa dan bertujuan untuk mencapai suatu tujuan belajar tertentu dengan cara memfasilitasi pengetahuan dan keterampilan siswa melalui kegiatan/ aktivitas yang dapat membantu dan memudahkan siswa dalam belajar. Maka, untuk menciptakan suasana yang harmonis, dan komunikatif, tugas guru adalah meningkatkan prestasi belajar serta senantiasa memberikan bimbingan dan pengarahan pada siswa.

Salah satu usaha guru untuk mengefektifkan pembelajaran PPKn di SMP Negeri 40 Makassar adalah dengan cara mengatasi kendala-kendala yang muncul pada saat pembelajaran PPKn, misalnya pada tahapan menanya, siswa masih perlu latihan untuk menyusun pertanyaan yang efektif, efisien dan sesuai dengan kaidah bahasa yang baik. Kepercayaan diri siswa masih kurang pada saat presentasi/ tahapan mengominkasikan. Hal tersebut diatasi dengan cara memberikan motivasi kepada siswa dengan memberikan tugas individu dan menyusun pertanyaan untuk mewujudkan rasa ingin tahunya terkait dengan materi pelajaran dan menggilir siswa menjadi ketua kelompok sehingga dapat membangun kepercayaan diri mereka.

Terlebih lagi, usaha guru untuk mengefektifkan pembelajaran PPKn adalah mengelola kelas dengan baik agar tercipta kondisi pembelajaran yang mendukung dan efektif. Hal tersebut dinyatakan dalam ungkapannya mengenai cara mengelola kelas, bahwa guru harus menguasai kelas dan anak-anak dikondisikan agar siap untuk menerima materi pelajaran.
Dari beberapa statemen di atas, dapat ditarik kesimpulan bahwa usaha mengefektifkan pembelajaran PPKn yang ada di SMP Negeri 40 Makassar adalah dengan 1) mengatasi kendalakendala yang muncul dalam wilayah di luar pembelajaran, seperti halnya pada tahapan menanya dan tahapan mengomunikasikan, 2) melakukan inovasi pembelajaran, dan 3) mengelola kelas dengan baik supaya tercipta kondisi pembelajaran yang efektif yang dapat menunjang pembelajaran yang efektif dan efisien

Sebenarnya efektifitas pembelajaran tersebut dapat ditinjau dari 3 segi, yaitu pemahaman, penyikapan dan pengimplementasian. Dalam pembelajaran PPKn, aspek pemahaman siswa merupakan aspek yang pertama kali ditekankan, karena tanpa pemahaman terhadap materi maka aspek yang selanjutnya tidak akan dapat diterima siswa dengan baik. Maksud dari pemahaman siswa di sini adalah siswa mampu memahami dan menguasai materi pembelajaran PPKn. Pembelajaran yang berlangsung dapat dikatakan efektif jika mampu membuat siswa menjadi paham terhadap apa yang diajarkan, seperti memiliki kepercayaan diri, mandiri, tanggung jawab, produktif dan kreatif dan lain sebagainya. Keefektifan ini tidak akan dapat dicapai tanpa adanya integrasi yang komprehensif dari berbagai elemen pembelajaran.

Dari peryataan di atas dapat di analisa bahwasannya dalam pembelajaran tanpa adanya perlengkapan, kesiapan dalam pembelajaran, tanpa adanya dukungan, keberhasilan dalam pembelajaran dikelas, maka suatu pembelajaran belum bisa dikatakan efektif dikarenakan belum bisa melengkapi pembelajaran itu sendiri.

\section{KESIMPULAN}

Pembelajaran yang telah dilakukan oleh guru dan siswa SMP Negeri 40 Makassar belum terlaksana secara efektif, hal ini dapat dilihat dari nilai siswa masih rendah atau belum optimal, sarana dan prasarana tidak mendukung dengan melakukan pendekatan saintifik yang ditandai dengan mengamati, menanya, mengumpulkan informasi/mencoba, menalar/mengasosiasi, 
mengomunikasikan. Langkah-langkah pembelajaran tersebut yang telah disusun berdasarkan rencana pelaksanaan pembelajaran (RPP) kurikulum 2013 tidak terlaksana dengan baik.

Dari hasil penelitian yang telah dilakukan pada SMP Negeri 40 Makassar tahun pelajaran 2016, diperoleh kesimpulan yang dapat dilihat dari proses pembelajaran yang berlangsung bahwa pendekatan saintifik belum dapat mengefektifkan pembelajaran PPKn pada SMP Negeri 40 Makassar.

\section{DAFTAR PUSTAKA}

[1] Abdul Kadir, dkk. 2012. Dasar-Dasar Pendidikan. Jakarta: Prenada Media Group.

[2] Daruma Razak, dkk. 2005. Perkembangan Peserta Didik. Makassar: Penerbit FIP-UNM.

[3] Handoko \& T. Hani. 2001. Manajemen. Yogyakarta: BPFE UGM.

[4] Iskandar Wiryokusumo \& J. Mandalika, ed. 1982. Kumpulan Pikiran-Pikiran Dalam Pendidikan. Jakarta: Rajawali Pers.

[5] Maharuddin Pangewa. 2010. Perencanaan Pembelajaran. Makassar: Badan Penerbit UNM.

[6] Martinis Yamin. 2003. Strategi Pembelajaran Berbasis Kompetensi. Ciputat: GP Press.

[7] Muis Saad \& Iman. 2004. Pendidikan Parsitipatif. Jakarta: Safira Insania Press.

[8] Muhibbin Syah. 2004. Psikologi Pendidikan Dengan Pendekatan Baru. Bandung: Rosda.

[9] Muhmidayeli. 2011. Filsafat Pendidikan. Bandung: PT Refika Aditama.

[10] Rusman. 2011. Model-Model Pembelajaran Mengembangkan Profesionalisme Guru. Jakarta: Rajawali Pers.

[11] Redja Mudyaharjo. 2001. Pengantar Pendidikan. Jakarta: PT Raja Grafindo Persada.

[12] Sutarjo Adisusilo. 2013. Pembelajaran Nilai Karakter. Jakarta: Rajawali Pers.

[13] Sardiman. 2011. Interaksi dan Motivasi Belajar Mengajar. Jakarta: Rajawali Pers.

[14] Steers \& Richard M. et.al. 1985. Efektivitas Organisasi. Jakarta: Erlangga.

[15] Sukmadinata \& Nana S. 2002. Pengendalian Mutu Sekolah Menengah: Konsep, Prinsip, dan Instrumen. Bandung: Remaja Rosda Karya.

[16] Sugiyono. 2010. Statistika Untuk Penelitian. Bandung: Alfabeta.

[17] Syamsul Bachri Thalib. 2010. Psikologi Pendidikan Berbasis Analisis Empiris Aplikatif. Jakarta: Kencana.

[18] Sugiyono. 2013. Metode Penelitian Pendidikan, Pendekatan Kuantitatif, Kualitatif, dan R\&D. Bandung: Alfabeta.
[19] Schunk Dale H, dkk. 2012. Motivasi Dalam Pendidikan, Teori, Pendidikan Dan Aplikasi. Jakarta: PT Indeks.

[20] The Liang Gie. 1989. Ensiklopedi Administrasi. Jakarta: PT Air Agung Putra.

[21] Wachyu Sundayana. 2014. Pembelajaran Berbasis Tema. Jakarta: Erlangga.

[22] Wina Sanjaya. 2006. Strategi Pembelajaran Berorientasi Standar Proses Pendidikan. Jakarta: Kencana. 